\title{
GENERALIZATION OF JENSEN'S AND JENSEN-STEFFENSEN'S INEQUALITIES BY GENERALIZED MAJORIZATION THEOREM
}

\author{
M. Adil Khan, JAMroz Khan AND JOSIP PEČARIĆ
}

\begin{abstract}
In this paper, we use generalized majorization theorem and give the generalizations of Jensen's and Jensen-Steffensen's inequalities. We present the generalization of converse of Jensen's inequality. We give bounds for the identities related to the generalization of Jensen's inequality by using Čebyšev functionals. We also give Grüss and Ostrowski types inequalities for these functionals. We present mean value theorems and $n$-exponential convexity which leads to exponential convexity and log-convexity for these functionals. We give some families of functions which enable us to construct a large families of functions that are exponentially convex and also give classes of means.
\end{abstract}

Mathematics subject classification (2010): 26D15.

Keywords and phrases: Jensen's inequality, Jensen-Steffensen's inequality, majorization, $n$-convexity, Čebyšev functional, Grüss type inequalities, Ostrowsky-type inequalities, exponentially convex functions, log-convex functions.

\section{REFERENCES}

[1] M. Adil Khan, N. Latif And J. PeČARIĆ, Generalization of majorization theorem, J. Math. Inequal., 9 (3) (2015), 847-872.

[2] M. Adil Khan, N. Latif, I. Perić And J. PeČarić, On Sapogov's extension of Čebyšev's inequality, Thai J. Math., 10 (2) (2012), 617-633.

[3] M. Adil Khan, Naveed Latif, I. Perić and J. PeČarić, On majorization for matrices, Math. Balkanica, 27 (2013), 13-19.

[4] M. Adil Khan, M. Niezgoda And J. PeČArić, On a refinement of the majorization type inequality, Demonstr. Math., 44 (1) (2011), 49-57.

[5] M. Adil Khan, SAdia Khalid AND J. PeČARIĆ, Refinements of some majorization type inequalities, J. Math. Inequal., 7 (1) (2013), 73-92.

[6] R. P. Agarwal, P. J. Y. Wong, Error Inequalities in Polynomial Interpolation and their Applications, Kluwer Academic Publisher, Dordrecht, 1993.

[7] A. A. AluiInovic, A. R. KhAn, J. PeČARIĆ, Weighted Majorization theorems via generalization of Taylor's formula, J. Inequal. and appl., 2015 (2015:196).

[8] A. A. Aljinović, J. PeČArić, And A. Vukelić, On some Ostrowski type inequalities via Montgomery identity and Taylor's formula II, Tamkang J. Math. 36 (4) (2005), 279-301.

[9] T. ANDo, Majorization, doubly stochastic matrices, and comparison of eigenvalues, Linear Algebra Appl. 118 (1989), 163-248.

[10] R. Bhatia, Matrix Analysis, Springer-Verlag, New York, 1997.

[11] R. P. BoAs, Representation of functions by Lidstone series, Duke Math. J. 10 (1943), 239-245.

[12] P. Cerone, S. S. Dragomir, Some new Ostrowski-type bounds for the Čebyšev functional and applications, J. Math. Inequal., 8 (1) (2014), 159-170.

[13] L. Fuchs, A new proof of an inequality of Hardy, Littlewood and Pólya, Mat. Tidsskr. B., 1947, $53-54$.

[14] G. A. Gazic, J. PeČArić, A. Vukelic, Generalization of Jensen's and Jensen-Steffensen's Inequalities and their converses by Lidstone's Polynomial and majorization theorem, submitted.

[15] J. JAKŠETIĆ, J. PeČARIĆ, Exponential Convexity Method, J. Convex Anal. 20 (1) (2013), 181-197. 
[16] A. R. KhAN, J. PeČARIĆ, M. R. LiPANOVIĆ, n-exponential convexity for Jensen-type inequalities, J. Math. Inequal. 7 (3) (2013), 313-335.

[17] A. W. MARShall, I. OlKin AND BARRy C. ARnOld, Inequalities, Theory of Majorization and Its Applications (Second Edition), Springer Series in Statistic, New York, 2011.

[18] J. PEČARIĆ, J. PERIĆ, Improvement of the Giaccardi and the Petrović Inequality and Related Stolarsky Type Means, A. Univ. Craiova Ser. Mat. Inform., 39 (1) (2012), 65-75.

[19] J. Pečarić, F. Proschan, Y. L. Tong, Convex Functions, Partial Orderings, and Statistical Applications, Academic Press, Inc., 1992.

[20] I. SCHUR, Über eine Klasse von Mittelbildungen mit Anwendungen die Determinanten-Theorie Sitzungsber, Berlin. Math. Gesellschaft, 22 (1923), 9-20.

[21] J. F. STEFFENSEN, On certain inequalities and methods of approximation, J. Inst. Actuaries 51 (1919), 274-297.

[22] D. V. Widder, The Laplace Transform, Princeton Univ. Press, New Jersey, 1941. 